\title{
Politika je častan i odgovoran poziv i zato političar mora biti pošten čovjek
}

\author{
Josip Jelenić*
}

\begin{abstract}
Sažetak
Polazište je rada tvrdnja pape Franje kako je politika častan oblik djelotvorne milosrdne ljubavi. Temeljem te tvrdnje, logički je zaključiti kako je samo vjerodostojno poštena osoba prikladna za politiku. Političari u svojem govoru i djelovanju moraju biti časni ljudi, a ne pokvareni, kako bi se mogli vjerodostojno zauzimati i promicati opće dobro. Pokvareni političari nemaju za cilj dobro građana, nego isključivo vlastite interese pa time stvaraju u cijelom društvu ozračje nepoštenja, koje se na društvenoj razini očituje kao grešne strukture. Istina je, postoje brojne zapreke njihovu poštenomu djelovanju. Ipak, to ih ne oslobađa obveze poštenja u zvanju političara.

Ključne riječi: korupcija, pokvarenost, politika, poštenje, odgoj, javno djelovanje, solidarnost, društvena pravednost
\end{abstract}

\section{Uvod}

Papa Franjo, pozivajući se na društveni nauk Crkve, u govoru u Ceseni tvrdi kako je politika »časni oblik milosrdne ljubavi« (Franjo, 2018, 6). ${ }^{1}$ Prema zakonu logike — časni posao obavlja časni čovjek — političar bi morao biti častan, pošten kako bi mogao odgovoriti časnomu pozivu. Jedino je častan političar sposoban zauzimati se za vjerodostojno dobro svih i svakoga u zajednici. Nažalost svakodnevna stvarnost pokazuje i potvrđuje nešto sasvim drugo. Svjedoci smo suprotnoga od očitovanih želja i načela. Postoje uzroci koji dovode čovjeka političara u „nečasno stanje“, koje se zatim prelijeva na okruženje u kojem djeluje. Zbog toga, smatram kako je svako ponovno promišljanje o izabranoj temi korisno te pomaže u traženju novih spoznaja i odstranjivanju svega onoga što priječi čovjeku političaru da svoj poziv obavlja časno i na dobro svih.

\footnotetext{
* Prof. dr. sc. Josip Jelenić, Papinsko sveučilište Gregoriana u Rimu. Adresa: Piazza della Pilotta 4,00187 Rim, Italija. E-pošta: jelenic@unigre.it

1 Citate iz izvora na talijanskom jeziku preveo je autor članka.
} 


\section{Politika nije izbor, nego dužnost}

Tim naslovom ne dovodim u pitanje temeljnu slobodu izbora niti sugeriram ovu ili onu političku opciju. Moje shvaćanje politike i njezine zadaće nalazi uporište u društvenom učenju Crkve, koje uvjetuje, određuje i vrednuje politički poziv u odnosu na djelotvornu zauzetost i promicanje pojedinačnog i općeg dobra. Drugi vatikanski sabor poziva sve

koji su sposobni ili bi se mogli osposobiti za političko zvanje, koje je teško ali ujedno i veoma plemenito, neka se pripremaju za nj i neka se trude da ga revno obavljaju ne mareći za svoju osobnu korist ni za materijalne probitke. Neka besprijekorno i razborito nastupaju protiv nepravde i nasilja, protiv samovolje vlasti i netolerantnosti pojedinog čovjeka ili političke stranke; neka se iskreno i pravično, dapače, s ljubavlju i političkom hrabrošću, posvete dobru svih (GS 75).

Citirani tekst iz Gaudium et spes opisuje i određuje politiku, političara i njegovo djelovanje. Politika kao zvanje ostvaruje se preko političara, tj. osobe koja pokreće i idejno usmjerava zajednicu u traženju najboljeg načina promicanja dobra svih. Njegovo razmišljanje i djelovanje ne smije oblikovati neka ideologija jer ona po naravi isključuje drugoga različitoga, tj. ne dopušta pluralizam ideja i izbora. Političar bi zapravo trebao biti prijenosnik ideje dobra prema i u zajednici kao i poticatelj njezina ostvarivanja.

Razmišljanje o politici i ljudima koji se bave politikom mora voditi računa o promjenama koje mogu biti poticaj za dobru politiku, kao i njezina zapreka. Redovito razmišljamo o nacionalnoj politici (unutar nacionalnog društva), a malo manje o međunarodnoj politici (unutar međunarodne zajednice). ${ }^{2}$ Donedavno je državna politika bila glavni predmet promišljanja, tj. politika jedne zemlje, države s točno određenim granicama unutar kojih je politika štitila nacionalne (državne) interese. To je opravdano procesom oblikovanja državnih zajednica koje su bile jamac samostojnosti, samodostatnosti i sigurnosti određenog naroda i nacije u odnosu na druge državne zajednice.

Takvo stanje pripada prošlosti jer je globalizacija unijela promjene koje su dovele do slabljenja uloge nacionalne države. Njezinu ulogu u oblikovanju politike preuzimaju, manje ili više, međunarodne institucije ili točnije, kompanije, tvrtke i osobito banke. Tako se „nacionalne politike“ pretvaraju u poslušne izvršitelje — više ili manje u korist vlastite nacije ${ }^{3}$ — „međunarodne politike“, koja se puno ne obazire na države i nacije. Takav proces pogoduje stvaranju ozračja podložnosti, u kojem se događa servilan odnos koji traži i očekuje, prije svega, osobnu korist ili onu stranačku, a ne opće dobro cijelog naroda. Stranačka ideologija, ${ }^{4}$ uz glo-

2 Takav pristup nije ništa neobično ni za društveni nauk Crkve. Na početku bavljenja društvenim pitanjima društveni nauk Crkve bio je zaokupljen više nacionalnom zajednicom unutar jedne države, a manje međunarodnom zajednicom. Takav tijek točno odgovara hodu razvoja i emancipiranja nacionalnih država, čija je uloga i važnost rasla sve do početka globalizacije.

3 To se odnosi na velike zemlje koje imaju golemu gospodarsku i financijsku moć.

4 Ideologija je prošla dug proces tijekom kojeg se udaljila od izvorne ideje. Termin ideologija prvi je upotrijebio francuski filozof Destutt de Tracy (1754.-1836.), koji ju je odredio kao „znanost 
balizaciju, drugi je čimbenik koji redovito ograničava političare u zauzimanju i promicanju dobra svih i svakoga u društvu.

Ti i drugi čimbenici doprinijeli su te na neki način uvjetovali ponašanje ljudi u ekonomiji i politici. Jedina važeća norma koja upravlja njihovim životom i djelovanjem je uspjeh, vlast i novac (bogatstvo). Riječ je o ideologiji učinkovitosti i uspjeha pod svaku cijenu, o ideologiji vladanja ne kao služenja nego kao gospodstva nad drugim, o ideologiji novca (materijalnog bogatstva) koje postaje svrha života i kriterij razmišljanja i djelovanja. Ako čovjek koji se posveti politici popusti toj trostrukoj napasti, čini sam sebe nesposobnim za promicanje općeg dobra. Politika koju provodi usmjerena je protiv dostojanstva i dobra drugih jer je zauzet samo vlastitim probitkom.

Političari i poslovni ljudi uvjetovani su gore spomenutim okolnostima. Time ne želim tvrditi kako su bez odgovornosti za ono što čine. Ona može biti umanjena no, ni u kojem slučaju posve uklonjena. U krajnjem slučaju, čovjek je uvijek odgovoran za svoj govor i djelovanje (Bogu, savjesti i bližnjemu). Tu istinu treba tim više ponavljati kao protutežu uhodanoj praksi, „svi tako čine! što ja tu mogu?“. To nikako nije način promicanja općeg dobra građana, nego znak slabića koji se vrte u pravcu trenutačnog političkog vjetra, koji svaki čas mijenja smjer. Nije riječ o prepoznavanju znakova vremena ${ }^{5}$ i potrebnim promjenama u duhu katoličkog društvenog učenja, nego znak nedoraslosti, često praćene bahatošću i neznanjem, zadatku i službi koje obnaša. Ako političari i ljudi koji obnašaju vlast u javnom području nisu sposobni čitati znakove vremena ni slobodno razlučivati, veoma će teško slijediti (moralno) dobro.

Koliko Crkva cijeni politiku i što očekuje od političara i od svih onih koji bi trebali promicati opće dobro najbolje svjedoče dokumenti Drugog vatikanskog sabora redovito praćeni i tumačenim socijalnim enciklikama. Riječ je o dekretu Apostolicam actuositatem o apostolatu laika i već citiranoj konstituciji Gaudium et spes. »Katolici koji su vješti za javne društvene dužnosti i upućeni u vjeri i kršćanskoj nauci kako odgovara, neka ne odbijaju obnašanje državnih službi« (AA 14). ${ }^{6}$ Gaudium et spes još je jasnija smatrajući političko zauzimanje zvanjem: »Koji su sposobni ili bi se mogli osposobiti za političko zvanje, koje je teško ali ujedno i veoma plemenito, neka se pripremaju za nj i neka se trude da ga revno obavljaju ne mareći za svoju osobnu korist ili za materijalne probitke«(GS 75). Od političara se traži besprijekornost i razboritost u borbi »protiv nepravde $\mathrm{i}$ nasilja, protiv samovolje vlasti i netolerantnosti pojedinog čovjeka ili političke

o idejama“ (Centro di studi filosofici, 1977, s. v. ideoligia). Ideje, u množini, koje se proučavaju i uspoređuju. Riječ je o pozitivnom pristupu. Nažalost, takvo razmišljanje o ideologiji „prošlo je kroz sito" individualizma i prosvjetiteljstva, koji su je odvojili od metafizike i odredili kao proizvod čovjekove iskustvene naravi. Time je dobila negativno značenje u smislu isključivosti: jedna jedina ideja. U nastavku dolaze razni izmi koji stvaraju vlastitu ideologiju, jednom idejom isključujući sve druge. To je plodno tlo za stvaranje totalitarnih sustava, diktatura različitih boja i usmjerenja.

5 Smisao i značenje sintagme ,znakovi vremena“ vidi u: PT 32; GS 4.

6 Tumačenje za „katolici i politika“ vidi u: Sorge, 2016, 264-275. 
stranke«(GS 75). Moraju promicati dobro svih »iskreno i pravično«, »s ljubavlju i političkom hrabrošću « (GS 75).

Navedeni tekst ne samo da cijeni političko zvanje, nego nudi i način kako ga ostvariti vjerodostojno, tj. poštenjem, besprijekornošću, tolerantnošću, razboritošću i političkom hrabrošću. To su nužne kvalitete ili kreposti koje, na svim razinama, moraju prožimati i krasiti čovjeka predanog politici. Riječ je o etičkim načelima na kojima nužno mora počivati političko djelovanje ako želi postići svoju svrhu. Uostalom, živeći navedene kvalitete, političar će se svesrdnije zauzimati za pravdu i opće dobro (GS 73). Drugim riječima, bez etike i morala političko djelovanje gubi svoje izvorno usmjerenje i vjerodostojnost te konačno postaje žrtva ideologijskih manipulacija. ${ }^{7}$

Nadalje, navodeći etiku i moral zajedno, želio sam istaknuti općenitost etike i osobnu posebnost morala. Kao što sam već prije spomenuo, etika propisuje načela jednako važeća za sve ljude polazeći od činjenice „čovjek“ (bez obzira na vjerske, etničke, kulturalne razlike), a moral je osoban i uči razlikovanje dobra od zla. Znači da svaki čovjek ima „vlastiti“ moral, jer razlikovanje dobra od zla i odluka koju moram donijeti osobna je i nitko drugi ju ne može donijeti umjesto mene. Moramo biti oprezni kako ne bismo zlorabili tu činjenicu. Imati vlastiti moral ne znači činiti što hoću i kako hoću, jer je isti podvrgnut načelu razlikovanja dobra od zla. Drugim riječima, dobro je osobna i društvena obveza. Promicati osobno i opće dobro potvrđuje da je čovjek moralan.

\section{Stvarni gospodari politike: ekonomija i banke}

Do sada smo govorili o uvjetovanosti izvršavanja političkog zvanja ideologijom. Nažalost ona nije jedina koja određuje tijek političkog djelovanja, nego se udružuje s ekonomijom i novčarskim institucijama ili bankama, koje prikriveno ili otvoreno diktiraju politiku. Postojeći sustav, na svjetskoj razini, funkcionira zahvaljujući svemoćnomu i točno razrađenomu bankovnomu sustavu. »Golema svota novca kreće se i obrće s jednog na drugi kraj planeta bez ikakvih razrađenih pravila « (Ciarrocca, 2013, 53). ${ }^{8}$ Taj prikriveni dio novca svjetske ekonomije i financija (zajedno s vidljivim dijelom), stvarno uvjetuje i usmjerava politiku na nacionalnim razinama, kao i svjetskoj razini. Postavlja se opravdano pitanje je li moguće u takvim okolnostima odgovoriti političkomu pozivu koji na prvo mjesto stavlja i zauzima se za pojedinačno i opće dobro u skladu s temeljnim načelom poštivanja dostojanstva svakog čovjeka i svake zajednice (naroda).

7 S obzirom na uvjetovanu povezanost političkog djelovanja s jedne strane i etike i morala s druge strane, treba usporediti razmišljanje Philipa Pettita, koji je uvjeren da ono »što je moralno nedopustivo također je nedopustivo i s političkog stajališta. Određena moralna načela također su temelj političkog djelovanja bez kojih je politika osuđena na neuspjeh. [...] Poštivanje drugoga temeljna je dimenzija politike jednako kao i u etici. [...] Zajednica i država poštuju osobu osiguravajući joj prostor osobnih sloboda i štiteći ju od uplitanja sloboda drugih«(Bagnoli, 2016, 27). Usp. također: Zsifkovits, 1996.

8 Ciarrocca tvrdi kako je riječ o 67 tisuća milijardi dolara. 
Treba se čuvati apriorističkog pristupa i odgovora, bilo pozitivnog bilo negativnog, i tražiti ga na temelju aposteriori promišljane stvarnosti koju svi proživljavamo. To znači shvatiti političku stvarnost kao mješavinu pozitivnoga i negativnoga, dobroga i lošega, dobronamjernih pokušaja i podmuklih podmetanja, uspjeha i neuspjeha. Uostalom, čitamo u Evanđelju, sa pšenicom raste i kukolj (Mt 13,24-30). Isusov odgovor kako treba ostaviti oboje, pšenicu i kukolj, da zajedno „rastu do žetve“ poziva nas da trajno činimo dobro bez obzira na prisutnost zla. Ako to pravilo igdje vrijedi, onda je to područje politike, tj. trajnog zauzimanja za dobro pojedinca i cijele zajednice, od čega nas nitko ne može osloboditi. Odgovorni smo, naime, osobno i u zajednici s drugima.

Vratimo se postavljenomu pitanju: Može li i u kojoj mjeri politika biti u službi djelotvornog promicanja općeg dobra? Sama logika stvarnosti u kojoj živimo određuje odgovor koji ne može biti nego potvrdan u smislu trajnog zauzimanja. Odlučujući se za takav odgovor, nužno je odgovoriti i na druga pitanja koja nam stvarnost nameće. Prije svega, je li moguće i na koji način osloboditi politiku od samodopadnog ponašanja banaka i ostalih financijskih institucija? Je li stvarno moguće i kako podložiti ekonomske i financijske centre moći razumnomu političkomu razlučivanju?

Jedan je od mogućih načina promicanje istinskih i zajedničkih vrednota u društvu u kojem živimo i radimo. Premda se to odnosi na svakog pojedinca u zajednici, mislim prije svega na „stvarne gospodare politike“, tj. ljude koji raspolažući s bogatstvom i moći mogu usmjeravati tijek povijesti. Oni u svojim rukama imaju stvarnu vlast koja diktira politička zbivanja u svijetu. Koje su to vrednote koje moramo promicati i živjeti po mjeri dostojanstva svakog čovjeka? Odgovori se mogu tražiti na dvije razine, institucionalno-tehničkoj i ljudskoj. U prvu skupinu rješenja ulaze napori samih institucija organizirajući se i djelujući na transparentan i odgovoran način. Moraju biti otvorene neovisnoj kontroli koja će bdjeti nad njihovim poslovanjem. ${ }^{9}$

Kako se dogodilo gospodstvo ekonomije i banaka nad politikom? Prema mišljenju Vincenza Rosita takav poredak plod je prelaska s političke teologije na ekonomsku teologiju, tj. »s prvotne usmjerenosti pozornosti na vlast i suverenitet, kao nezaobilaznog elementa u tumačenju političko-državnog autoriteta, prešlo se na analizu upravo administrativnih, upravljačkih i dakle ekonomskih funkcija koje sada obavlja političar « (Rosito, 2016, 34). Drugim riječima, politika gubi usmjerenost na osobe, subjekte te se istodobno okreće prema materijalnim objektima. To znači degradaciju političkog zvanja i funkcija, čime se stvara okruženje podložnosti isključivo materijalnim i novčarskim interesima pojedinaca ili skupina. Takav razvoj doprinosi stvaranju „političkih elita“ u negativnom smislu, koje postaju pokriće stvarnim gospodarima, tj. gospodarskim i novčarskim interesnim skupinama (Habermas, 2012, 73). Politika u takvom okruženju niti služi niti promiče opće dobro svih i svakoga, nego isključivo interese povlaštenih pojedinaca i skupina.

9 Solidnu analizu stvarnog gospodarskog i političkog stanja nudi Joseph E. Stiglitz (2010). 
U takvom nezdravom okruženju svi koji se posvećuju politici moraju se suočiti s izravnim posljedicama vladanja političkih elita, tj. prisiljeni su slijediti strategiju lobija, ${ }^{10}$ koji po svojoj naravi ne promiču opće nego pojedinačno, odnosno skupno „dobro“ te na taj način proturječiti njihovu političkomu pozivu, koji bi se morao ostvarivati po mjeri dostojanstva svakog čovjeka. Kada promatramo ponašanje i djelovanje političara pojedinaca i političkih institucija u trenutačnoj složenoj situaciji, uočavamo dva bitna sudionika: poštenog pojedinca (osobu) i izopačene institucije (D’Ambrosio, 2011, 145). Što se događa u takvoj situaciji s poštenim političarom? D'Ambrosio svjedoči: »U institucijama u kojima se korumpirani uvijek osjećaju u miru sa svojom savješću, jedini su pošteni koji postaju skrupulozni, pitajući se svaki trenutak što bi trebalo činiti« (D’Ambrosio, 2011, 145). ${ }^{11}$ Prema društvenom nauku Crkve riječ je o grešnim strukturama koje onemogućuju, bilo pojedincu bilo institucijama, promicanja općeg dobra (SRS 36). Ne samo političari, nego svi oni koji se bave javnim poslovima, djeluju u okruženju grešnih struktura. Što to znači i kakve su posljedice?

Grešne strukture ustvari konačni su rezultat pojedinačnih, osobnih grijeha koji se prenose i truju naš međurelacijski život te se na taj način oblikuju u mrežu grešnih odnosa i djelovanja. Čitamo u Kompendiju: »Posljedice grijeha podupiru strukture grijeha. One se ukorjenjuju u osobnom grijehu i zato su, dakle, uvijek povezane s konkretnim djelima osoba koje ih uzrokuju, učvršćuju i čine ih teško uklonjivima. I one se tako jačaju, šire, postaju izvor drugih grijeha i uvjetuju ponašanje ljudi« (CSDC 119). Izvor su dakle uvijek osobni grijesi (samo osoba kao slobodan čovjek može sagriješiti) koji djelovanjem postaju društveni grijesi obuhvaćajući osobe, strukture i institucije. ${ }^{12}$ Grešne strukture zamagljuju jasan uvid u stvarnost i tako iskrivljuju istinu. Osobni i društveni grijeh iskrivljuje stvarnost: laž postaje istinom i istina se predstavlja kao laž na svim područjima javnog života. ${ }^{13}$

Ivan Pavao II., imajući na umu upravo te činjenice, tvrdi kako »među deformacijama demokratskog sustava politička je korupcija jedna od najgorih, jer istodobno izdaje načela morala i norme socijalne pravednosti « (CSDC 411). ${ }^{14}$ Politička pokvarenosti, tj. političara (i države) razara i uništava cijelo društvo: »kompromitira ispravno funkcioniranje i negativno utječući na odnos između vladajućih i podanika; uvodi sve veće nepovjerenje prema javnim ustanovama, uzrokujući postupno pomanjkanje odvažnosti građana prema politici i njezinim predstavnicima, zbog čega dolazi do slabljenja ustanova (CSDC 411). Točnije »korupcija iskrivljuje ulogu zastupničkih ustanova u korijenu, jer se njima koristi kao terenom političke razmjene između klijentelističkih zahtjeva i usluga

10 O naravi i svrsi lobija vidi: Pritoni, 2018.

11 D'Ambrosio se oslanja na Kalvinovu misao (D'Ambrosio, 2011, 145, bilj. 59).

12 Više o grešnim strukturama vidi u: Bastianel, 1989.

13 Primjerice na gospodarskom i financijskom području jedna od laži koja se koristi kao „istina“ je „svi imaju koristi od bogatstva malo bogatih“ (Bauman, 2013).

14 U hrvatskom jeziku korumpiranost se može prevesti pokvarenošću. Zašto, dakle, ne bi upotrijebili hrvatsku riječ koja bolje izriče sadržaj i stanje subjekta? 
vladajućih. Na taj način, politički odabiri pospješuju uske ciljeve onih koji imaju sredstva da na njih utječu te sprečavaju općeg dobra svih građana« (CSDC 411).

Riječi Ivana Pavla II. izriču dijagnozu ponašanja nositelja političkih i javnih dužnosti u hrvatskom društvu i državi. Svjedoci smo svakodnevnih otkrivanja oblika pokvarenosti tolikih ljudi u politici: podmićivanje, klijentelizam, primanje mita, nepoštenje u privatnom i javnom životu, laži, osobno bogaćenje na račun općeg dobra i socijalne pravednosti, prikrivanje nepravde na svim razinama društvenog života, omalovažavanje institucija pred društvom. Takvo (političko) ponašanje stvara odbojnost građana prema javnom životu i politici općenito, nepovjerenje u institucije (i državu), bezvoljnost u privatnom i javnom životu. ${ }^{15}$ Građani se zatvaraju u sebe, gdje su izloženi napasti sebičnosti i pretjeranog individualizma. Gube povjerenje u sebe i u druge. ${ }^{16}$

Naslovio sam ovaj dio razmišljanja Stvarni gospodari politike: ekonomija $i$ banke. Znači da su političari samo izvršitelji odluka drugih, često u sjeni, a ne stvarni subjekti političkih odluka te kao takvi ne mogu promicati opće dobro svih građana. U takvom ozračju i djelovanju stvara se pretjerana birokratizacija cjelokupnog političkog javnog djelovanja »koja se potvrđuje kada institucije koje postajući organizacijski sve složenije i u težnji da popune sva područja, završe u ponorima bezličnog funkcionalizma, pretjerane birokracije, nepravednih privatnih interesa, olakog i općeg nemara« (CSDC 412). Logično je pitanje: Jesu li političari — i općenito ljudi koji su odgovorni za javni život u društvu i državi — svjesni svih onih negativnosti i gorkih plodova koje donosi njihovo neodgovorno ponašanje? Ako su svjesni i ne čine ništa da to isprave, dvostruko su pokvareni! Ako nisu svjesni, treba ih pozvati na promjenu u duhu (stvarnih) obećanja dana građanima koji su ih izabrali.

\section{3. Što činiti kako bi javno političko djelovanje ponovno postalo vjerodostojno?}

Nije lako odgovoriti na postavljeno pitanje. Prije svega, treba se čuvati rješenja po logici dobro-zlo, crno-bijelo. Jednako tako, ne postoji brzo rješenje ad $h o c$, nije moguća promjena preko noći. Riječ je prije svega o procesu, o zahtjevnom tijeku koji ne trpi „skokove“, nego ustrajnost i upornost u osobnom i ko-

15 Društvo se pretvara u „bojno polje“ jer se želja za individualnom srećom sukobljava s nastojanjem kolektivnog oslobađanja. Rezultat je samodopadna neodgovorna demokracija (Orsina, 2018).

16 Kad je riječ o hrvatskom društvu, iseljavanje građana u druge zemlje, po mojem mišljenju, ima dvostruki razlog. Prvo, građani su povrijeđeni u njihovu dostojanstvu kao osobe jer su upotrijebljeni (tijekom izbora). Drugo, često nedostaje potrebno za osobni i obiteljski život, tj. siromaštvo u okruženju snalažljivih bogatih. Rad niti se nudi niti se cijeni. Od njega se ne živi. „Važno je biti na liniji i sve ćeš imati." Podsjećam na poruku pape Franje upućenu sudionicima 48. Socijalnog tjedna talijanskih katolika, u kojoj se ističe nastojanje za rad koji će biti slobodan, stvaralački, sudjelujući i solidaran (Di Santo, 2017). To treba biti jedan od prvih ciljeva svakog poštenog političara. 
lektivnom formiranju, odgajanju. Već sam spomenuo kako je jedan od mogućih izlaza iz takve situacije formiranje i promicanje određenih društvenih ili socijalnih vrednota, kao primjerice pravednost i solidarnost, koje su nužno potrebne za uređeni zajednički život u društvu.

\subsection{Odgajanje u duhu socijalne ili društvene pravednosti}

Svi građani jedne države moraju se odgajati u nastojanju za društvenu pravednost, ili riječima Mattea Zuppija: »svi moramo polagati račun društvenoj pravednosti« (Goldkorn, 2018). Tim više to vrijedi za ljude koji se odlučuju za obnašanje javnih funkcija u društvu s ciljem osiguranja općeg dobra svih. Prevedeno rječnikom svakodnevnog života, zauzimanje za društvenu pravednost znači biti djelatno odgovoran za sebe i za druge, za svoje djelovanje i za djelovanje drugih, biti odgovoran za međuodnose koje promičem. Takva se odgovornost postvaruje (konkretizira, potvrđuje, prevodi) poštivanjem dostojanstva osobe (građanina) ako je osoba, a ne politički glas ili stranački ideologijski broj. ${ }^{17}$

Opisanu društvenu pravednost, tj. zauzimanje za nju, društveni nauk Crkve poistovjećuje s promicanjem općeg dobra, svakog pojedinca i cijelog društva. Nadalje, ostvarivanje društvene pravednosti u duhu i prema načelu općeg dobra uključuje i pravednu raspodjelu dobara kao prvi znak ozbiljno shvaćene pravednosti (QA 58, 59 i 109). Prema tome, jedna je od prvih zadaća političara zdušno zauzimanje da »svatko dobije njegov dio dobara, tj. treba se truditi da se stvorena dobra razdjele u skladu s propisima općega dobra, odnosno društvene pravednosti« (QA 59). ${ }^{18}$ Drugim riječima, pravedno ponašanje općenito i posebno u političkom javnom djelovanju stječe vjerodostojnost kada daje Bogu Božje, a bližnjemu ono što mu pripada, ne po načelu ujednačene pravednosti (iustitiae distributivae), nego prema stvarnim potrebama i tko traži pomoć. Pravednost, uostalom, čini osobe jednakima i ide za tim da ljudi prime ono što im treba, a koje se određuje ne prema trenutačnoj ili prošloj funkciji, nego prema dostojanstvu osobe. ${ }^{19}$ Pravednost je krepost, a ne trenutačni zanos pa, prema tome, mora biti promicana uvijek i svugdje. ${ }^{20}$

17 Dakako, treba imati na umu kako je ljudska pravda ograničena, manjkava (LP 3).

18 U nastavku Pio XI. piše: »To više, kad svatko razuman zna kako su zatrovani današnji odnosi zbog goleme razlike između nekolicine silno bogatih ljudi i bezbroj siromaha (QA 59). Iako je tekst pisan 1931., nije nažalost izgubio nimalo na svojoj aktualnosti. Štoviše, danas je još očitiji, bolniji i sramotniji rastući jaz između bogatih i siromašnih, kojemu se ne vidi kraj.

19 Smatram od velike važnosti da svaka osoba koja sudjeluje u javnom političkom djelovanju shvati i prihvati, kao načelo osobnog i političkog djelovanja, pravednost koja na razini osobe ne čini nikakve razlike između ljudi (građana). U praktičnom smislu, takvo pravedno djelovanje, primjerice u biranju suradnika (u strukturama vlasti) za javne službe, nespojivo je s namještanjem nesposobnih prijatelja, rodbine ili stranačkih istomišljenika. Predlažu se i biraju u javne službe stručno sposobni i pošteni.

20 Ponašanje nekih naših političara očito i nedvojbeno odudara od dosljedne primjene načela pravednosti u javnom djelovanju. Oni često čine kompromise koji jedanput primijenjeni postaju pravilo općeg ponašanja i odlučivanja. Plodovi su svima vidljivi i nanose štetu većini, kao i općemu dobru cijele zajednice. 
Tako shvaćena i primjenjivana pravednost istodobno doprinosi pozitivnomu ozračju u cijelom društvu: budi nadu i potiče na zauzetost za zajedničko dobro. Život i djelovanje po načelu pravednosti pomaže dobronamjernim i zauzetim građanima da se još više zauzimaju za opće dobro, a istodobno umanjuje slobodni prostor i oduzima opravdanje onima koji nastoje djelovati nepravedno. Podsjećam ponovo kako nije riječ o nekoj nestvarnoj i nedostižnoj pravednosti. Istinska pravednost, naime, teži stvarnomu ostvarivanju u konkretnim prilikama i mogućnostima, po mjeri svakog čovjeka i prema njegovim stvarnim potrebama u svakodnevnom životu.

Pravednost koja polazi od dostojanstva svakog čovjeka (i prema svakomu čovjeku) nužno je praćena i potaknuta razboritošću i istinom..$^{21}$ Prva se predstavlja kao sposobnost prepoznavanja onoga što je pravično i služi kao preduvjet ostvarivanja pravednosti. S obzirom na istinu nemoguće je biti pravedan i istodobno lagati (davati lažno svjedočanstvo o sebi i drugima). Jedno isključuje drugo. Onaj koji laže nije slobodan za promicanje osobnog i općeg dobra. Samo istina nas oslobađa od bilo kojeg ropstva. Dosljedno tomu, govor i djelovanje javnih djelatnika (političara) mora biti svjedočenje za istinu u konkretnim životnim prilikama. ${ }^{22}$ Samo razborit i istinoljubiv političar (svi koji po svojem pozivu djeluju za opće dobro) može biti vjerodostojan svjedok časnosti politike (političkog djelovanja) kao izravnog načina zauzimanja i promicanja općeg dobra. Zanimljivo je podsjetiti na radioporuku Pia XII. iz 1944. u kojoj je govorio o osobinama koje u demokratskom sustavu moraju krasiti (ili prožimati) one koji obnašaju javnu vlast: izabrani predstavnici u saboru i vladi, politički djelatnici. Moraju, prije svega, biti učinkovito uvjereni u njihovoj savjesti kako su dostojanstvo čovjeka, države i vlasti međusobno povezani. To istodobno mora biti i kriterij njihova izbora od strane građana (biračkog tijela) (Pio XII., 1991). ${ }^{23}$

Jednako nastojanje, uz odgajanje za pravednost, mora biti posvećeno formiranju u duhu solidarnosti, tj. za solidarnost. ${ }^{24}$ Riječ je o vrlini i kvaliteti koja nužno mora prožimati i usmjeravati život svih onih koji se posvećuju javnomu djelovanju. Podsjetimo se kako solidarnost nije »osjećaj neke neodređene sućuti ili površnog ganuća zbog patnji tolikih ljudi«, nego »čvrsta i postojana odlučnost zauzeti se za opće dobro, to jest za dobro svih i svakoga, jer svi smo mi uistinu za sve odgovorni« (SRS 38). Govor je o solidarnosti kao kvaliteti, kreposti koja

21 O sadržaju i svrsi istine i razboritosti vidi u: YOUCAT 299 i 301.

22 „Političke laži“ ne mogu se dugo skrivati jer se „drvo pozna po plodovima“. Nadalje, u istinski demokratskom sustavu moguće je boriti se protiv takvih pojava na zakonit i djelotvoran način.

23 Papa Pio XII. govorio je o odlikama koje moraju krasiti predstavnike naroda, tj. javne političke djelatnike. Između ostaloga, smatra da treba izabrati ljude »solidnog kršćanskog uvjerenja, pravičnog i sigurnog prosuđivanja, koji imaju osjećaja za praktičnost i pravednost, dosljedne samima sebi u svim okolnostima; ljude zdravog i jasnog učenja, dosljednih i postojanih odluka; ljude sposobne [...] biti vođe i upravitelji [...], ljude jasnih pogleda, brižljive dobrote, i pravednosti prema svima [...], ljude koji će promicati iskreno bratstvo« (Pio XII., 1944).

24 Bez vjerodostojne solidarnosti jedva je moguć demokratski sustav. Istinska demokracija, ustvari, počiva na solidarnosti koja ju hrani iznutra, daje joj vanjski oblik i čini stvarnom. Više o odnosu demokracije i solidarnosti vidi u: Bauer, 1978. 
treba krasiti svakog čovjeka, a osobito kršćanina. ${ }^{25}$ Svi građani moraju nastojati uzajamno se pomagati i međusobno surađivati za dobro svakoga i svih zajedno. To par excellence vrijedi za ljude u politici, vlasti i svih onih koji sudjeluju u javnom životu društva.

Političar koji živi, gore definiranu, vrlinu solidarnosti lakše će se boriti protiv raznih oblika individualizma, sebičnosti, klijentelizma, pohlepe i nametanja vlastite volje, što je sve suprotno općemu dobru (SRS 39). Nadalje, živjeti solidarnost pomaže političarima da na vrijeme razotkrivaju „grešne strukture“ i da se bore protiv njih (SRS 39). Konačno, pomaže građanima, osobito onima koji se bave politikom, da drugoga promatraju ne kao neko sredstvo čiju radnu sposobnost i tjelesnu snagu i politički glas, »treba iskoristiti uz nisku cijenu, i kad nam više ne koristi, onda ga ostaviti, nego kao nama 'sličnoga', kao našu 'pomoć' «, tj. kao osobu (SRS 39).

Dodajmo rečenomu kako zauzetost i promicanje društvene pravednosti i solidarnosti mora biti prije svega usmjereno protiv korupcije (pokvarenosti) u svim njezinim oblicima. Ona je u temelju svakog ropstva, nezaposlenosti, zapostavljanja općeg dobra. Papa Franjo tvrdi: »Korupcija je smrtni proces koji hrani kulturu smrti« jer »pohlepa za vlašću i posjedovanjem ne pozna granice« (Franjo, 2018). Nadalje, ističe Papa, »protiv korupcije se ne bori šutnjom. Moramo govoriti glasno (protiv korupcije), prokazivati zla« i boriti se protiv njih. Svi oni koji su u službi javnog dobra - političari, gospodarstvenici, koji imaju vlast — ne smiju se voditi korupcijom (Franjo, 2018).

\section{Zaključak}

Pisati i razmišljati o korupciji, koja vodi u pokvarenost, znači podsjećati na nešto što, u većoj ili manjoj mjeri, postoji u svim društvima i svim razdobljima, nešto što je uobičajeno i sastavni je dio čovjekova javnog djelovanja. Ako je tako, u čemu je onda novost? Zašto govoriti o nečemu što svi znamo? Mislim da je novost u stvaranju novih „suvremenih“ oblika korupcije pod utjecajem novih lokalnih, nacionalnih i međunarodnih procesa kao primjerice globalizacije, jačanje lobija na svim razinama, nametnuto gospodstvo anonimnih društava, slabljenja uloge nacionalne države. Svi ti elementi zajedno stvaraju izazove i pozive ljudima u vlasti i javnom djelovanju. Uvjetuju ih, ograničavaju i stavljaju na kušnju, „provjeravaju“ njihov karakter i moral, njihovo poštenje. Ipak, i pored svega toga, moguće je iskorjenjivati korupciju u javnom djelovanju. Štoviše, to nam je dužnost i obveza. Trajnim odgajanjem i formiranjem građana u duhu poštenja — konkretno za društvenu pravednost i solidarnost — pružamo priliku da i na odgovorna mjesta u državi dođu pošteni i sposobni ljudi. Poziv je upućen svima. Kakav je moj, naš odgovor? 


\section{Literatura:}

AA. Apostolicam actuositatem. U: Josip Turčinović (prir.), II. vatikanski koncil: Dokumenti: Latinski i hrvatski: IV. izdanje (str. 417-466). Zagreb: Kršćanska sadašnjost, 1986.

Bagnoli, Carla (2016). Non c'è politica senza morale. Il Sole 24Ore, 278, 27. URL: http://www.ilsole24ore.com/art/cultura/2016-10-07/non-c-e-politica-senza-morale-182457.shtml?uuid=ADYW9ZWB\&refresh_ce=1 (15.03.2018.)

Bastianel, Sergio (ur.) (1989). Strutture del peccato: Una sfida teologica e pastorale. Casale Monferrato: Piemme.

Bauer, Riccardo (1978). Breviario della democrazia. Milano: Pan Editrice.

Bauman, Zygmunt (2013). „La ricchezza di pochi avvantaggia tutti“: Falso! Bari: Laterza.

Centro di studi filosofici (1977). Dizionario delle idee. Firenca: Sansoni.

Ciarrocca, Luca (2013). I padroni del mondo: Come la cupola della finanza mondiale decide il destino dei governi e delle popolazioni. Milano: Chiaralettera.

CSDC. Compendium of the Social Doctrine of the Church. Papinsko vijeće Iustitia et pax, Kompendij socijalnog nauka Crkve. Zagreb: Kršćanska sadašnjost, 2005.

D'Ambrosio, Rocco (2011). Come pensano e agiscono le istituzioni. Bologna: EDB.

Di Santo, Gianni (2017). Senza lavoro non c'è dignità: Monito della Chiesa contro la dosoccupazione. L'Eco di S. Gabriele, 105(12), 24-25.

Franjo (2018). La corruzione nutre la cultura della morte. L'Osservatore romano. URL: http://www.osservatoreromano.va/it/la-corruzione-nutre-la-cultura-della-morte (29.04.2018)

Goldkorn, Wlodek (2018). „Il nulla non ci avrà“: Colloquio con Matteo Zuppi. L'Espresso, 4 (21. siječnja), 83.

GS. Gaudium et spes. U: Josip Turčinović (prir.), II. vatikanski koncil: Dokumenti: Latinski i hrvatski: IV. izdanje (str. 619-761). Zagreb: Kršćanska sadašnjost, 1986.

Habermas, Jürgen (2012). Questa Europa è in crisi. Rim — Bari: Laterza.

LP. Libertas praestantissimum. Lav XIII., Litterae encyclicae sanctissimi domini nostri Leonis divina providentia papae XIII ad patriarchas, primates, archiepiscopos et episcopos universos catholoci orbis, gratiam et communionem cum Apostolica Sede habentes de libertate humana. URL: http://w2.vatican.va/content/leo-xiii/la/encyclicals/documents/ hf_l-xiii_enc_20061888_libertas.html (15.03.2018.)

Orsina, Giovanni (2018). La provocazione: il 1968 è stato l'anno in cui è nato il rancore. L'Espresso, 18. siječnja. URL: http://espresso.repubblica.it/plus/articoli/2018/01/17/ news/la-provocazione-il-1968-e-stato-1-anno-in-cui-e-nato-il-rancore1.317236?refresh_ce (15.03.2018.)

Pio XII. (1991). Radio-poruka upućena cijelom svijetu na Badnjak 24. prosinca 1944. U: Marijan Valković (ur.), Socijalni dokumenti Crkve: Sto godina katoličkoga socijalnog nauka (str. 91-105). Zagreb: Kršćanska sadašnjost.

PT. Pacem in terris. Ivan XXIII., Pacem in terris: Encikličko pismo [...] o miru svih naroda što ga je utemeljiti na istini, pravednosti, ljubavi i slobodi. U: Marijan Valković (ur.), Socijalni dokumenti Crkve: Sto godina katoličkoga socijalnog nauka (str. 163-202). Zagreb: Kršćanska sadašnjost, 1991.

Rosito, Vincenzo (2016). Lo spirito e la polis: Prospettiva per una pneumantologia politica. Assisi: Cittadela.

Pritoni, Andrea (2018). Lobby d'Italia: Il sistema degli interessi tra Prima e Seconda Repubblica. Rim: Carocci.

QA. Quadragesimo anno. Pio XI., Enciklika Quadragesimo anno: Enciklika Njegove Svetosti pape Pija XI. katoličkom svijetu u povodu četrdesete obljetnice „Rerum nova- 
rum“. U: Marijan Valković (ur.), Socijalni dokumenti Crkve: Sto godina katoličkoga socijalnog nauka (str. 31-78). Zagreb: Kršćanska sadašnjost, 1991.

Sorge, Bartolomeo (2016). Introduzione alla dottrina sociale della Chiesa: Seconda allargata edizione. Brescia: Queriniana.

SRS. Solicitudo rei socialis. Ivan Pavao II., Socijalna skrb: Solicitudo rei socialis. Zagreb: Kršćanska sadašnjost, 1998.

Stiglitz, Joseph E. (2010). Bancarotta: L'economia globale in caduta libera. Torino: Einaudi.

YOUCAT. Youth catechism. Biskupska konferencija Austrije i Biskupska konferencija Njemačke i Švicarske, Youth catechism per conoscere e vivere la fede della Chiesa: Seconda edizione premessa di papa Benedetto XVI. Na talijanski preveo Pietro Podolak. Rim: Città Nuova, 2011.

Zsifkovits, Valentin (1996). Politika bez morala? Zagreb: Školska knjiga.

Politics is an Honourable and Responsible Vocation and so too a Politician Must be

Josip Jelenic**

\section{Summary}

Pope Francis, in quoting the social teaching of the Church in Cesena, Italy, affirms that politics is "a very honourable form of charitable love". Based on this claim, it is logical to conclude that only an honest and credible person is suited for politics. It is imperative that politicians, both in their speech and in their actions, be honourable and in no way morally corrupt in order that they may become engaged for and promote the common good. Depraved politicians do not have as their goal the good of citizens, but rather only their own interests, and so they create an atmosphere of dishonesty in all of society. On the societal level this is manifested in the form of sinful structures. In truth, there exist numerous obstacles to honourable activity, still, this fact does not exempt politicians from their obligation to be honest in their vocation as politicians.

Key words: corruption, depravity, politics, honesty, upbringing, public activity, solidarity, social justice

* Professor Josip Jelenić, Ph.D., Pontifical Gregorian University. Address: Piazza della Pilotta 4, 00187 Rome, Italy. E-mail: jelenic@unigre.it 